\title{
Seasonality of Pelecinus polyturator (Drury) (Hymenoptera, Pelecinidae) in the Atlantic Rainforest of São Paulo State, Brazil
}

\author{
Rogéria I. R. Lara ${ }^{1} \&$ Nelson W. Perioto ${ }^{2}$
}

\begin{abstract}
'Polo Centro Leste, Ribeirão Preto, Agência Paulista de Tecnologia dos Agronegócios (APTA), Av. Bandeirantes 2419, 14030-670, Ribeirão PretoSP, Brazil. rirlara@yahoo.com.br

${ }^{2}$ Programa de Pós-graduação em Agronomia (Entomologia Agrícola), Faculdade de Ciências Agrárias e Veterinárias, Universidade Estadual Paulista "Júlio de Mesquita Filho" (UNESP), Via de Acesso Prof. Paulo Donato Castellane s/n, 14888-900, Jaboticabal-SP, Brazil. nperioto2@gmail.com
\end{abstract}

\begin{abstract}
Seasonality of Pelecinus polyturator (Drury) (Hymenoptera, Pelecinidae) in the Atlantic Rainforest of São Paulo State, Brazil. A survey of the parasitoid wasp Pelecinus polyturator (Drury, 1773) (Hymenoptera, Pelecinidae) was carried out with five Malaise traps/area in five areas in the Atlantic Rainforest of São Paulo State, Brazil, between November 2009 and October 2010. The sampling effort in each locality amounted to 1,825 trap-days. Data were obtained from a total of 317 exemplars of P. polyturator, corresponding to 108 females and 209 males. The average sex ratio of the studied population was 0.52 . The highest occurrence of $P$. polyturator was observed between November and March with frequency peak in January; about $95 \%$ of the specimens studied were captured at altitudes close to $1,000 \mathrm{~m}$ above sea level.
\end{abstract}

KEYWORDS. Insecta; Neotropical; Phyllophaga; population fluctuation; Proctotrupoidea.

Pelecinus Latreille, 1800 (Hymenoptera, Pelecinidae) is the only genus of Pelecinidae, a morphologically unusual group of wasps characterized by the female's slender and strikingly long body. The genus is restricted to the continental New World and contains only three extant species: P. thoracicus Klug, 1841, P. dichrous Pert, 1833 and P. polyturator (Drury, 1773). The latter species is the most widely distributed in the genus, with its range extending from southern portions of the eastern provinces of Canada (about $51^{\circ} \mathrm{N}$ ), the USA (North Dakota, Colorado and New Mexico) and southern Mexico to Argentina (about $38^{\circ}$ S) (Johnson \& Musetti 1998, 1999).

Brues (1928) stated that P. polyturator presents geographic parthenogenesis. In North America, the species reproduces primarily by thelytokous parthenogenesis - males are rarely collected and are restricted to certain areas - while the same is not observed in tropical areas farther south, where the species presents bisexual populations.

The biology and behavior of $P$. polyturator are poorly known; they act as solitary koinobiont endoparasitoids of larvae of Phyllophaga anxia (LeConte, 1850), P. inversa (Horn, 1887), P. drakei Kirby, 1837, P. rugosa (Melsheimer, 1846) (Coleoptera: Scarabaeidae, Melolonthinae) and Podischnus agenor Olivier, 1789 (Coleoptera: Scarabaeidae, Dynastinae) (Lim et al. 1990; Johnson \& Musetti 1998; Masner 2006). The females oviposit into larvae that sometimes reach the pupal stage before dying (Clausen 1940).

Despite its large size and relatively common occurrence in areas of Atlantic Rainforest, little has been documented about seasonal and/or population fluctuations of $P$. polyturator. The main goal of this study was to provide information on the sea- sonality of $P$. polyturator in five areas in the Atlantic Rainforest of São Paulo State, Brazil.

\section{MATERIAL AND METHODS}

Specimens of Pelecinus were sampled from five areas of the Atlantic Rainforest of São Paulo State, Brazil (Fig. 1), between November 2009 and October 2010: Estação Ecológica Juréia-Itatins (EEJI) (2431'14.6”'S/47¹2'5.7'W), Iguape municipality; Parque Estadual Intervales (PEI) (24 ${ }^{\circ} 16^{\prime}$ 28.0"S/48 $\left.25^{\circ} 14.8^{\prime} \mathrm{W}\right)$, Ribeirão Grande municipality; Parque Estadual do Morro do Diabo (PEMD) (22³6' 17.0"S/ $52^{\circ} 18^{\prime} 05.8^{\prime \prime}$ ), Teodoro Sampaio municipality; Parque Estadual da Serra do Mar, Núcleo Santa Virgínia (PESM/

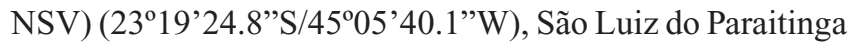
municipality, and Núcleo Picinguaba (PESM/NP) (23ำ' 59.3"S/4449'57.8”W), Ubatuba municipality. The surveys were authorized by the Sistema de Autorização e Informação em Biodiversidade (SISBIO), license \#10632-1. Five Malaise traps (Townes 1972) were used in each area, distant 50 meters apart, with Dietrich solution as a preservative, operated continuously. The biological material was removed monthly, and corresponded to one sample. The total sampling effort in each locality amounted to 1,825 trap-days.

The identifications of Pelecinus were carried out using the key proposed by Johnson \& Musetti (1999) and the specimens were deposited at the Coleção Entomológica do Laboratório de Sistemática e Bioecologia de Parasitoides e Predadores (LRRP) of APTA Ribeirão Preto, Ribeirão Preto, SP, Brazil (N.W. Perioto, curator). 


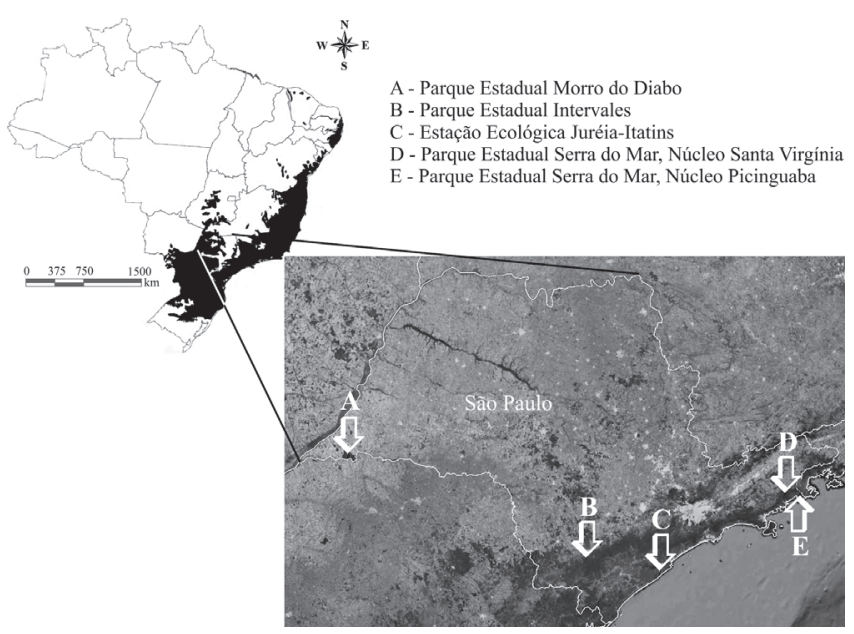

Fig. 1. Study sites in the Atlantic Rainforest of São Paulo State, Brazil. Image sources: www.wwf.org.br and Google Earth.

\section{RESULTS AND DISCUSSION}

Data were obtained from a total of 317 exemplars (108 females $/ 34.1 \%$ and 209 males/65.9\%) of $P$. polyturator, of which 175 exemplars $(55.2 \%$ of the total) were collected at PESM-NSV, $131(41.3 \%)$ at PEI, 10 (3.2\%) at PESM-NP and, one $(0.3 \%)$ at EEJI. No specimens were collected at PEMD (Table I).

The female:male sex ratio was on average 0.52:1.00 (0.43-0.54:1.00). These findings agree with those of Brues (1928) and Johnson \& Musetti (1998), which stated that the average sex ratio for southern populations was $0.36: 1.00$ (0.20-0.60:1.00).

The highest occurrence of $P$. polyturator (307 exemplars, $96.8 \%$ of the total) was observed between November and March with frequency peak in January (102/32.2\%) (Table I, Fig. 2). As males and females had similar population fluctuations it is plausible to assume that their flight activities

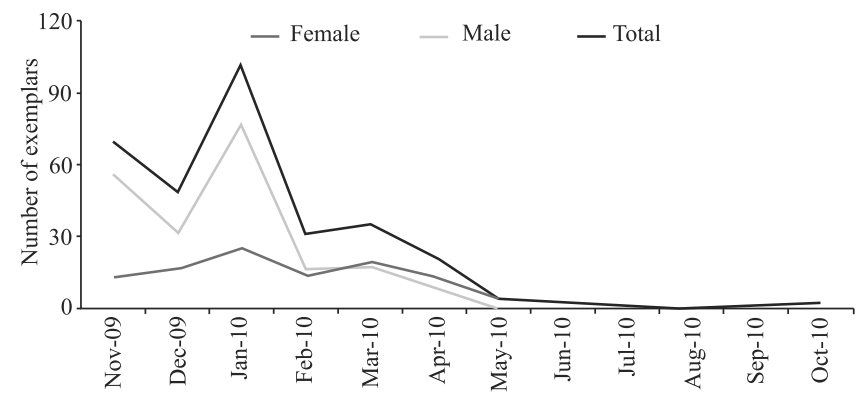

Fig. 2. Seasonality of Pelecinus polyturator (Drury, 1773) (Hymenoptera, Pelecinidae) collected with Malaise trap in five areas of Atlantic Rainforest at São Paulo State, Brazil, between November 2009 and October 2010.

are concomitant in the studied areas, which corroborates the data of Johnson \& Musetti (1998).

The observed abundance of $P$. polyturator was low, but it was expressive regarding the sampling effort employed. The species was more frequent at PESM-NSV (1,030 $\mathrm{m}$ above sea level - asl) where the sampling effort to catch each specimen was 10.4 trap-days, followed by PEI ( $880 \mathrm{~m}$ asl) with 13.9 trap-days/specimen, PESM-NP (215 m asl) with 182.5 trap-days/specimen, and EEJI (16 m asl) with 1,825 trapdays/specimen. It should be noted that at PESM-NP and EEJI, the sampling effort to trap one specimen of $P$. polyturator was almost 30 times greater than at PESM-NSV and PEI. Johnson \& Musetti (1999) stated that Pelecinus seems to be largely absent from the lowlands in the tropics and commonly seen at mid elevations $(1,000 \pm 3,000 \mathrm{~m})$. The data obtained in areas of Atlantic Rainforest of São Paulo State confirm those observations since about $95 \%$ of the exemplars studied were captured at altitudes close to $1,000 \mathrm{~m}$ asl.

Several authors have reported the inability of Malaise traps in sampling the fauna of Hymenoptera in a given environment (Noyes 1989; García 2003; Campbell \& Hanula 2007, Aguiar \& Santos 2010) and that, at least for some groups, it

Table I. Number of specimens of Pelecinus polyturator (Drury, 1773) (Hymenoptera, Pelecinidae) collected with Malaise traps at Estação Ecológica Juréia-Itatins (EEJI), Parque Estadual Intervales (PEI), Parque Estadual do Morro do Diabo (PEMD), Parque Estadual da Serra do Mar: Núcleo Santa Virgínia (PESM/NSV) and Núcleo Picinguaba (PESM/NP), São Paulo State, Brazil, between November 2009 and October 2010.

\begin{tabular}{|c|c|c|c|c|c|c|c|c|c|c|c|c|c|c|c|c|c|c|}
\hline \multirow{2}{*}{ Month/year } & \multicolumn{3}{|c|}{$\mathrm{PESM} / \mathrm{NSV}$} & \multicolumn{3}{|c|}{ PEI } & \multicolumn{3}{|c|}{$\mathrm{PESM} / \mathrm{NSV}$} & \multicolumn{3}{|c|}{ EEJI } & \multicolumn{3}{|c|}{ PEMD } & \multicolumn{3}{|c|}{ TOTAL } \\
\hline & $\mathrm{F}$ & $\mathrm{M}$ & $\Sigma$ & $\mathrm{F}$ & $\mathrm{M}$ & $\Sigma$ & $\mathrm{F}$ & $\mathrm{M}$ & $\Sigma$ & $\mathrm{F}$ & $\mathrm{M}$ & $\Sigma$ & $\mathrm{F}$ & $\mathrm{M}$ & $\Sigma$ & $\mathrm{F}$ & $\mathrm{M}$ & $\Sigma$ \\
\hline November-09 & 11 & 25 & 36 & 2 & 31 & 33 & 0 & 0 & 0 & 0 & 0 & 0 & 0 & 0 & 0 & 13 & 56 & 69 \\
\hline December-09 & 16 & 15 & 31 & 1 & 17 & 18 & 0 & 0 & 0 & 0 & 0 & 0 & 0 & 0 & 0 & 17 & 32 & 49 \\
\hline January-10 & 16 & 46 & 62 & 6 & 25 & 31 & 3 & 6 & 9 & 0 & 0 & 0 & 0 & 0 & 0 & 25 & 77 & 102 \\
\hline February-10 & 14 & 15 & 29 & 0 & 2 & 2 & 0 & 0 & 0 & 0 & 0 & 0 & 0 & 0 & 0 & 14 & 17 & 31 \\
\hline March-10 & 3 & 8 & 11 & 15 & 9 & 24 & 0 & 0 & 0 & 0 & 0 & 0 & 0 & 0 & 0 & 18 & 17 & 35 \\
\hline April-10 & 1 & 5 & 6 & 12 & 3 & 15 & 0 & 0 & 0 & 0 & 0 & 0 & 0 & 0 & 0 & 13 & 8 & 21 \\
\hline May-10 & 0 & 0 & 0 & 4 & 0 & 4 & 0 & 0 & 0 & 0 & 0 & 0 & 0 & 0 & 0 & 4 & 0 & 4 \\
\hline June-10 & 0 & 0 & 0 & 2 & 0 & 2 & 0 & 0 & 0 & 0 & 0 & 0 & 0 & 0 & 0 & 2 & 0 & 2 \\
\hline July-10 & 0 & 0 & 0 & 0 & 0 & 0 & 0 & 0 & 0 & 1 & 0 & 1 & 0 & 0 & 0 & 1 & 0 & 1 \\
\hline August-10 & 0 & 0 & 0 & 0 & 0 & 0 & 0 & 0 & 0 & 0 & 0 & 0 & 0 & 0 & 0 & 0 & 0 & 0 \\
\hline September-10 & 0 & 0 & 0 & 0 & 0 & 0 & 0 & 1 & 1 & 0 & 0 & 0 & 0 & 0 & 0 & 0 & 1 & 1 \\
\hline October-10 & 0 & 0 & 0 & 1 & 1 & 2 & 0 & 0 & 0 & 0 & 0 & 0 & 0 & 0 & 0 & 1 & 1 & 2 \\
\hline Total & 61 & 114 & 175 & 43 & 88 & 131 & 3 & 7 & 10 & 1 & 0 & 1 & 0 & 0 & 0 & 108 & 209 & 317 \\
\hline$\%$ & & & 55.2 & & & 41.3 & & & 3.2 & & & 0.3 & & & 0.0 & 34.1 & 65.9 & 100.0 \\
\hline
\end{tabular}

$\mathrm{F}=$ female $\mathrm{M}=$ male $\boldsymbol{\Sigma}=$ total of female and male. 
captures differentially determined sex (Aguiar \& Santos 2010). However, the results obtained in this study indicate that Pelecinus polyturator can be collected in great number with Malaise traps in high-altitude areas, if used for long periods and with multiple repetitions.

\section{ACKNOWLEDGMENTS}

We thank the Instituto Nacional de Ciência e Tecnologia dos Hymenoptera Parasitoides da Região Sudeste Brasileira (Hympar/Sudeste - CNPq/Fapesp/Capes) for the financial support.

\section{REFERENCES}

Aguiar, A.P. \& Santos, B.F. 2010. Discovery of potent, unsuspected sampling disparities for Malaise and Möricke traps, as shown for Neotropical Cryptini (Hymenoptera, Ichneumonidae). Journal of Insect Conservation 14: 199-206.

Brues, C.T. 1928. A note on the genus Pelecinus. Psyche 35: 205-209.

Campbell, J.W. \& Hanula, J.L. 2007. Efficiency of Malaise traps and colored pan traps for collecting flower visiting insects from three forested ecosystems. Journal of Insect Conservation 11: 399-408.

Clausen, C.P. 1940. Entomophagous Insects. New York, McGraw-Hill Book Company, $688 \mathrm{p}$.

García, J.M. 2003. Comparación de la captura de Hymenoptera (Insecta) mediante cuatro métodos de muestreo, en los cerros Yaví y Yutajé del Pantepui venezolano. Entomotropica 18: 27-35.

Johnson, N.F. \& Musetti, L. 1998. Geographic variation of sex ratio in Pelecinus polyturator (Drury) (Hymenoptera: Pelecinidae). Journal of Hymenoptera Research 7: 48-56.

Johnson, N. F. \& Musetti, L. 1999. Revision of the proctotrupoid genus Pelecinus Latreille (Hymenoptera: Pelecinidae). Journal of Natural History 33: 1513-1543.

Lim, K.P., Yule, W.N. \& Stewart, R.K. 1980. A note on Pelecinus polyturator (Hymenoptera: Pelecinidae), a parasite of Phyllophaga anxia (Coleoptera: Scarabaeidae). Canadian Entomologist 112: 219-220.

Masner, L. 2006. Familia Pelecinidae, p. 239-241. In: Hanson, P.E. \& Gauld, I.D. (Eds.). Hymenoptera de la Región Neotropical. Gainesville, American Entomological Institute, 994 p.

Noyes, J.S. 1989. A study of five methods of sampling Hymenoptera (Insecta) in a tropical rainforest, with special reference to the Parasitica. Journal of Natural History 23: 285-298.

Townes, H.A. 1972. A light-weight Malaise trap. Entomological News 83: $239-247$. 